\title{
ABSOLUTE CHRONOLOGY OF MEGIDDO, ISRAEL, IN THE LATE BRONZE AND IRON AGES: HIGH-RESOLUTION RADIOCARBON DATING
}

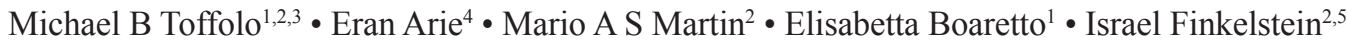 \\ ABSTRACT. Megiddo (Israel) is a key site for the study of the stratigraphy, chronology, and history of the Bronze and \\ Iron ages in the Levant. The article presents a Bayesian chronological model for seven ceramic typology phases and 10 \\ stratigraphic horizons at this site, covering the Late Bronze and much of the Iron Age. The model is based on 78 samples, \\ which provided 190 determinations - the most thorough set of radiocarbon determinations known so far in a single site in the \\ Levant. This set of data provides a reliable skeleton for the discussion of cultural processes and historical events in the region \\ and beyond, including the periods of the Egyptian Empire in Canaan and the Northern Kingdom of Israel.
}

\section{INTRODUCTION}

The relative chronology of the Levant in the Late Bronze and Iron ages is well studied. It has been established by investigating typological differences in large pottery assemblages. Thus, scholars can now accurately identify five Late Bronze Age horizons (hereafter LB IA, IB, IIA, IIB, and III; e.g. Panitz-Cohen 2006; Mullins 2007; Gadot 2009; Martin 2013; Arie 2013b) and six Iron Age horizons (early and late Iron I, early and late IIA, IIB, and IIC - e.g. Zimhoni 2004; Herzog and Singer-Avitz 2004, 2006; Arie 2006, 2013c) for this timespan, which covers approximately a millennium. Yet, the absolute chronology of these horizons is debated, for instance, regarding the beginning of the LB (see below), the LB I-II, the details of the LB III/Iron I transition, ${ }^{6}$ and the Iron I/II transition (e.g. Sharon et al. 2007; Mazar and Bronk Ramsey 2008; Finkelstein and Piasetzky $2010 \mathrm{~b})$. This is so because of the lack of well-dated finds, such as monuments and royal-name items of Egyptian monarchs, in Levantine strata representing much of this sequence. And this, in turn, hinders a proper reconstruction of the history of the Levant, for example, regarding the exact time of the transformation of the region into an Egyptian New Kingdom province; the process of collapse of the Egypto-Canaanite system at the end of the Late Bronze Age; and the rise of territorial kingdoms such as Israel, Judah, and Damascus in the Iron Age.

Rigorous programs of dating the Iron Age phases have been underway in the last decade (e.g. Boaretto et al. 2005; Sharon et al. 2007; Mazar and Bronk Ramsey 2008; Finkelstein and Piasetzky 2010a). Dates for Late Bronze strata have also been published (e.g. Carmi and Ussishkin 2004 for Lachish; Mazar et al. 2005 for Rehov; Mazar 2007, 2009 for Beth-Shean; Boaretto et al. 2009 for Aphek; Figure 1), but no comprehensive project for dating the entire Late Bronze sequence has thus far been attempted.

Models that use dates for samples that were retrieved in a large number of sites, such as those suggested for the Iron Age, have clear advantages, e.g. in their geographical scope, but face methodological problems such as different sample-retrieval procedures and inclusion of sites with less-

1. Weizmann Institute-Max Planck Center for Integrative Archaeology, D-REAMS Radiocarbon Laboratory, Weizmann Institute of Science, Rehovot, Israel.

2. Sonia and Marco Nadler Institute of Archaeology, Tel Aviv University, Tel Aviv, Israel.

3. Corresponding author. Email: michael.toffolo@weizmann.ac.il.

4. Samuel and Saidye Bronfman Archaeology Wing, The Israel Museum, Jerusalem, Israel.

5. Michael B Toffolo is a PhD candidate at Tel Aviv University, working on the theme of Levantine and Aegean chronology in the Iron Age under the supervision of Israel Finkelstein and Elisabetta Boaretto; Mario A S Martin and Eran Arie are senior staff members of the Megiddo Expedition, the supervisors of Areas $\mathrm{K}$ and $\mathrm{H}$ and experts of Late Bronze and Iron Age pottery; Elisabetta Boaretto is the Director of the D-REAMS Radiocarbon Laboratory at the Weizmann Institute of Science and track leader of the European Research Council project (below); Israel Finkelstein is the Director of the Megiddo Expedition and P.I. of the European Research Council under the European Community's Seventh Framework Programme (FP7/2007-2013)/ ERC project, grant agreement $n^{\circ} 229418$.

6. With LB III we refer to the period of the 20th Dynasty in Egypt. Others, e.g. Mazar, label this phase Iron IA. 


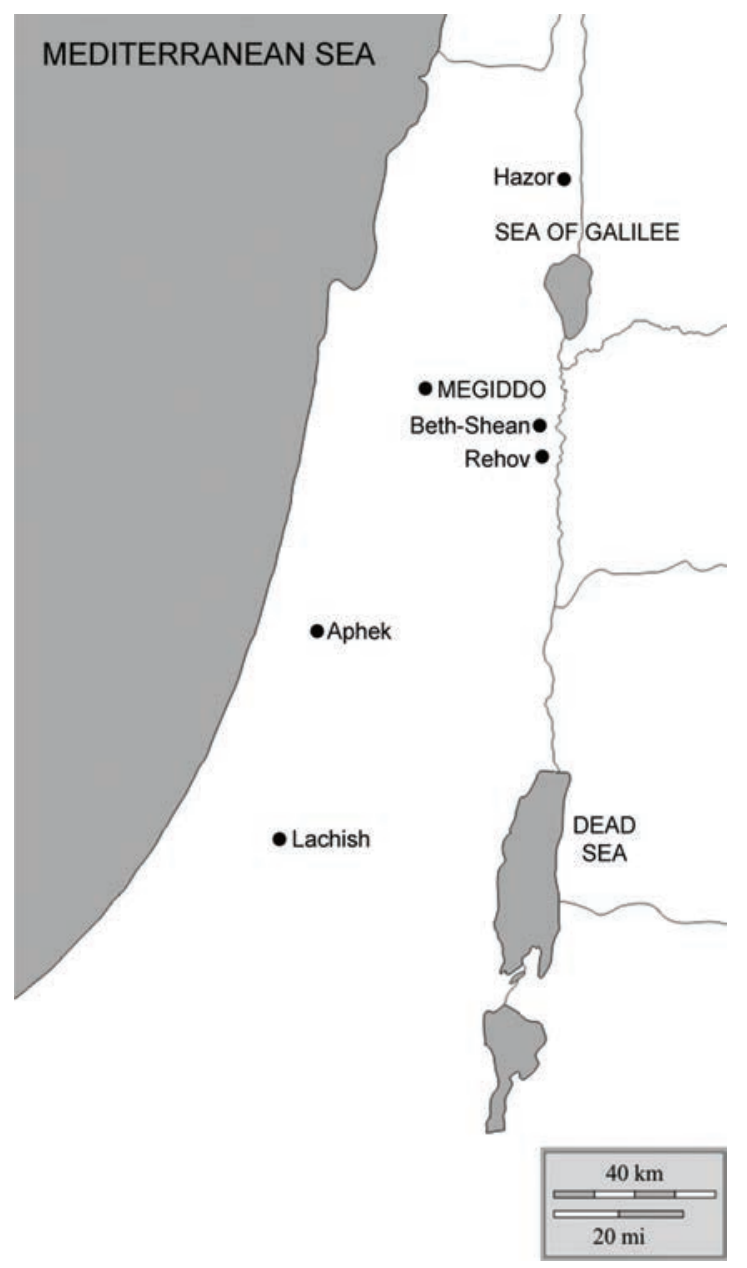

Figure 1 Map of southern Levant showing the Iron Age sites mentioned in the article.

than-ideal ceramic control and different methods of excavation. Thus, voices have been raised regarding the need to establish a full absolute sequence in a single site (Levy et al. 2010:844). This should ideally be done with the involvement of the radiocarbon laboratory experts in the field. The advantage of such an endeavor is in the unified methods of decisions regarding context, retrieval of samples, and recording.

This article presents a full ${ }^{14} \mathrm{C}$ Bayesian model of the Late Bronze and Iron Age phases at Tel Megiddo, Israel (Figure 1). This is the most complete dating program applied to a single multilayered site and the first full ${ }^{14} \mathrm{C}$-based model for the Late Bronze Age. Megiddo has long been considered a key site for the archaeology of the Levant (e.g. Davies 1986; Kempinski 1989), including the chronologies of both the Late Bronze and the Iron Age. The presented model covers 10 stratigraphic phases (Table 1) and is based on 190 determinations from 78 samples, retrieved from four different excavation areas. This is the most comprehensive dating project thus far undertaken in any single site in the Levant. It sheds light on a large number of archaeological and historical issues, especially those related to the Egyptian rule in Canaan in the Late Bronze Age and the struggle between the territorial kingdoms of the Iron Age as recorded in written sources, including the Hebrew Bible. 
Table 1 The Megiddo levels discussed in this article, by area.

\begin{tabular}{|c|c|c|c|c|}
\hline Level & Relative chronology & Nature of stratum & $\begin{array}{l}\text { Ref. to stratigraphy } \\
\text { and architecture }\end{array}$ & Ref. to pottery \\
\hline \multicolumn{5}{|c|}{ Area $\mathrm{K}$} \\
\hline $\mathrm{K}-4$ & Late Iron I & $\begin{array}{l}\text { Large, rectangular } \\
\text { courtyard house, } \\
\text { massive destruc- } \\
\text { tion }\end{array}$ & Gadot et al. 2006a & Arie 2006 \\
\hline K-5 & Early Iron I & $\begin{array}{l}\text { Fragmentary remains } \\
\text { of a domestic } \\
\text { building }\end{array}$ & Gadot et al. 2006a & Arie 2006 \\
\hline K-6 & LB III & $\begin{array}{l}\text { Courtyard building } \\
\text { with olive-oil } \\
\text { installation }\end{array}$ & Arie and Nativ 2013 & Arie $2013 a$ \\
\hline $\mathrm{K}-7$ & LB IIB & $\begin{array}{l}\text { Domestic buildings, } \\
\text { slight changes in } \\
\text { the plan of Level } \\
\text { K-8 }\end{array}$ & Martin et al. 2013 & Martin 2013 \\
\hline $\mathrm{K}-8$ & LB IIB & Domestic buildings & Martin et al. 2013 & Martin 2013 \\
\hline K-9 & LB IIA & $\begin{array}{l}\text { Domestic building; } \\
\text { evidence for long- } \\
\text { term occupation }\end{array}$ & Not published yet & Not published yet \\
\hline $\mathrm{K}-10$ & Late MB-LB I & $\begin{array}{l}\text { Domestic architecture } \\
\text { and intramural } \\
\text { burials }\end{array}$ & Not published yet & Not published yet \\
\hline \multicolumn{5}{|c|}{ Area $\mathrm{H}$} \\
\hline H-5 & Late Iron IIA & Plastered piazza & Arie 2013a & Arie $2013 \mathrm{c}$ \\
\hline $\mathrm{H}-7$ & Early Iron IIA & $\begin{array}{l}\text { Domestic occupation; } \\
\text { thick accumulation } \\
\text { of floors }\end{array}$ & Arie $2013 a$ & Arie $2013 \mathrm{c}$ \\
\hline H-9 & Late Iron I & Patrician house & Arie $2013 a$ & Arie $2013 b$ \\
\hline $\mathrm{H}-10$ & Early Iron I & Pillared building & Not published yet & Not published yet \\
\hline H-11 & Early Iron I & $\begin{array}{l}\text { Fragments of building } \\
\text { surrounded by } \\
\text { courtyards; jewelry } \\
\text { hoard }\end{array}$ & Not published yet & Not published yet \\
\hline $\mathrm{H}-12$ & $\begin{array}{l}\text { LB III and early } \\
\text { Iron I }\end{array}$ & $\begin{array}{l}\text { Large courtyards with } \\
\text { very thick accumu- } \\
\text { lation of floors }\end{array}$ & Not published yet & Not published yet \\
\hline $\mathrm{H}-13$ & LB IIB & Elaborate building & Not published yet & Not published yet \\
\hline \multicolumn{5}{|c|}{ Area M } \\
\hline M-4 & Late Iron I & $\begin{array}{l}\text { Public building } \\
\text { (shrine?) and relat- } \\
\text { ed remains }\end{array}$ & $\begin{array}{l}\text { Franklin 2013; } \\
\text { Pechuro 2013; } \\
\text { Finkelstein } 2013\end{array}$ & Arie $2013 b$ \\
\hline M-6 & LB III & $\begin{array}{c}\text { End phase of a large } \\
\text { public building } \\
\text { (the Nordburg) }\end{array}$ & $\begin{array}{l}\text { Franklin 2013; } \\
\text { Pechuro 2013; } \\
\text { Finkelstein 2013 } \\
\end{array}$ & Arie $2013 b$ \\
\hline \multicolumn{5}{|l|}{ Area $\mathrm{F}$} \\
\hline $\mathrm{F}-10$ & LB I & Domestic buildings & Franklin 2006 & Gadot et al. $2006 \mathrm{~b}$ \\
\hline
\end{tabular}




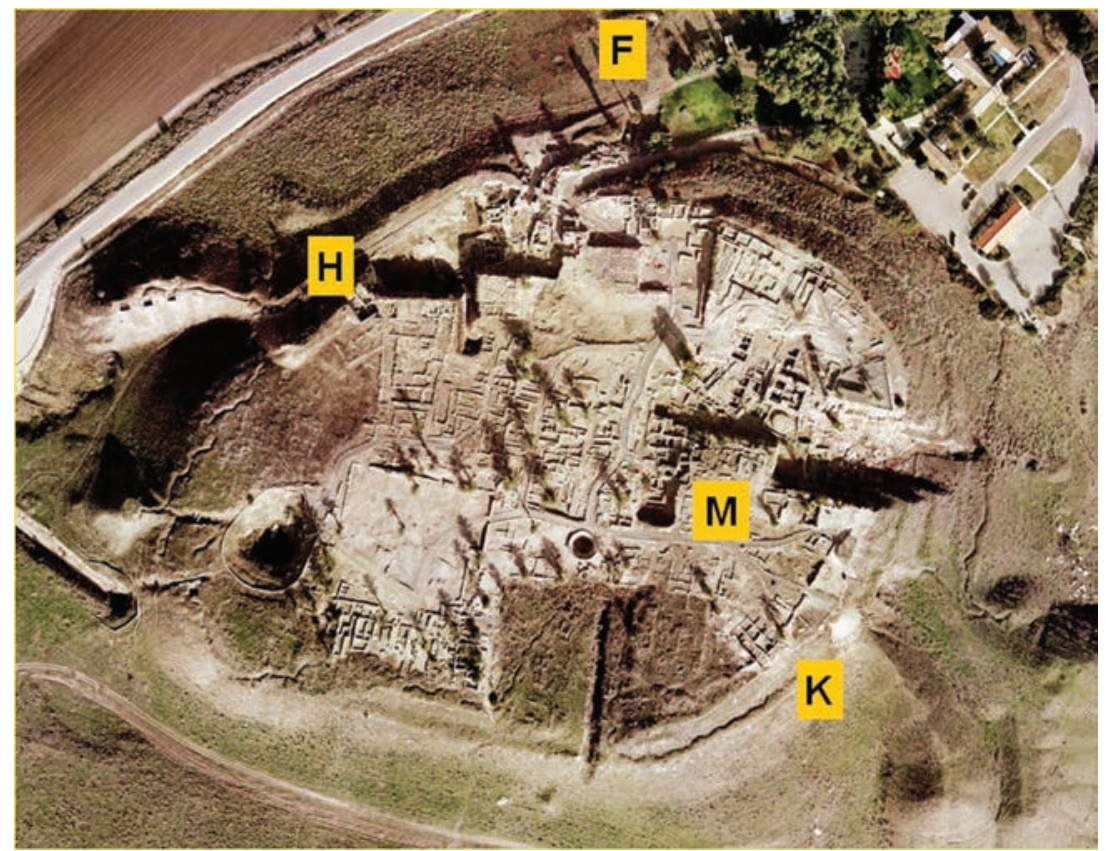

Figure 2 Aerial view of Tel Megiddo, indicating the location of the excavation areas that provided the samples for ${ }^{14} \mathrm{C}$ dating.

\section{Megiddo}

Megiddo is the ultimate site for a full chronological model for the Late Bronze and Iron ages. This is so for the following reasons:

- The site was inhabited continuously, with no major occupational gaps (differing from Hazor, for instance, which was deserted in the LB III and in part of the Iron I, and Lachish, which was abandoned in the Iron I).

- The Late Bronze-Iron Age layers were uncovered in two sectional trenches located on the edge of the tell in different sectors of the site: Area K, characterized by domestic habitations, and Area $\mathrm{H}$, close to the gate and the palace (Figure 2). The two trenches are large enough $(15 \times 25$ and $10 \times$ $20 \mathrm{~m}$, respectively) to enable establishing a solid stratigraphic sequence (Figures 3-4). Additional data come from Area M, located in the center of the site, and Area F on its lower terrace. In addition to the construction of a full chronological model, this opens the way for intrasite observations.

- The site is being carefully excavated. The ratio of experienced archaeologists to student volunteers in each area is 1-to-4 or -5. The pace of excavation is slow: in Area K, for instance, the floors of Level K-10 (end of the Middle Bronze and beginning of the Late Bronze), located $\sim 5 \mathrm{~m}$ below the current surface of the mound, were reached after $\sim 55$ weeks of excavations in nine seasons.

- The Late Bronze-Iron Age sequence at Megiddo features an unparalleled series of four destruction layers (Figure 5). Because they feature large assemblages of finds, they can serve as reliable pegs that enable secure control over phases of ceramic typology (relative chronology) and provide an especially large number of samples for ${ }^{14} \mathrm{C}$ dating.

- Because of the importance of the site, its ceramic assemblages include Egyptian and Aegean forms, which can help establishing chronological links with neighboring lands. 


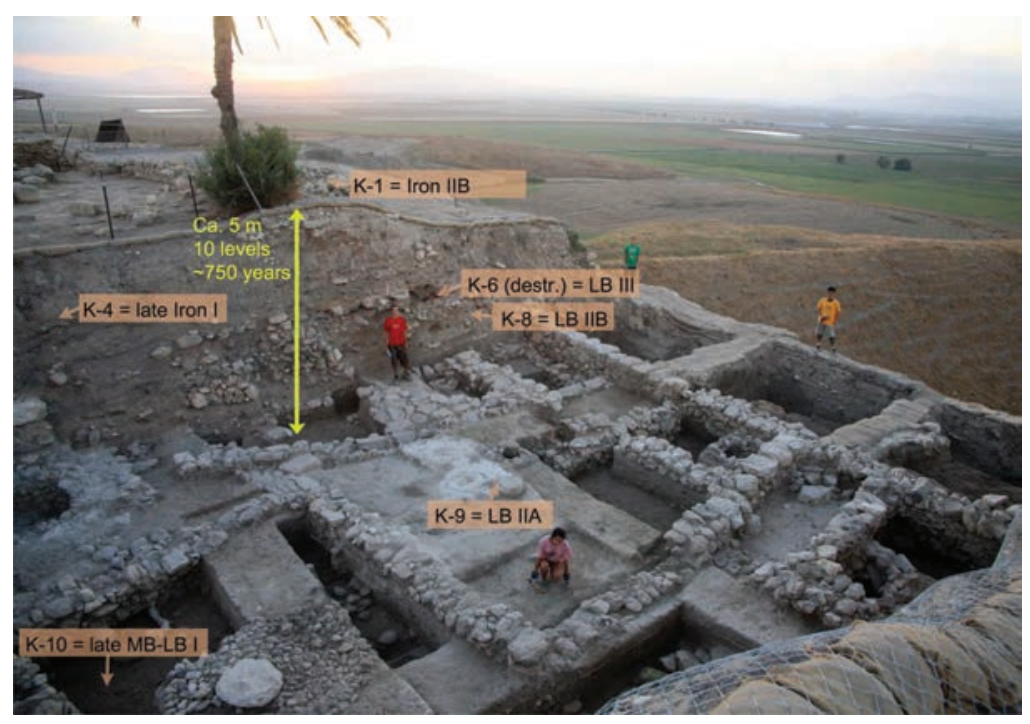

Figure 3 General view of Area $\mathrm{K}$ pointing to some of the levels mentioned in the text

- Last but not least, Megiddo is mentioned in a plethora of written sources (it is the only site in the Levant that is mentioned in all great archives/writings of the ancient Near East-Egyptian, Assyrian, the Hebrew Bible, and a single Hittite document), in connection to major events in the Late Bronze-Iron Age sequence. They facilitate links between the archaeological and historical records.

No other site in the Levant features this set of factors.

Tables 1-2 summarize the nature of the levels discussed in this paper, their relative chronology and stratigraphic relationship.

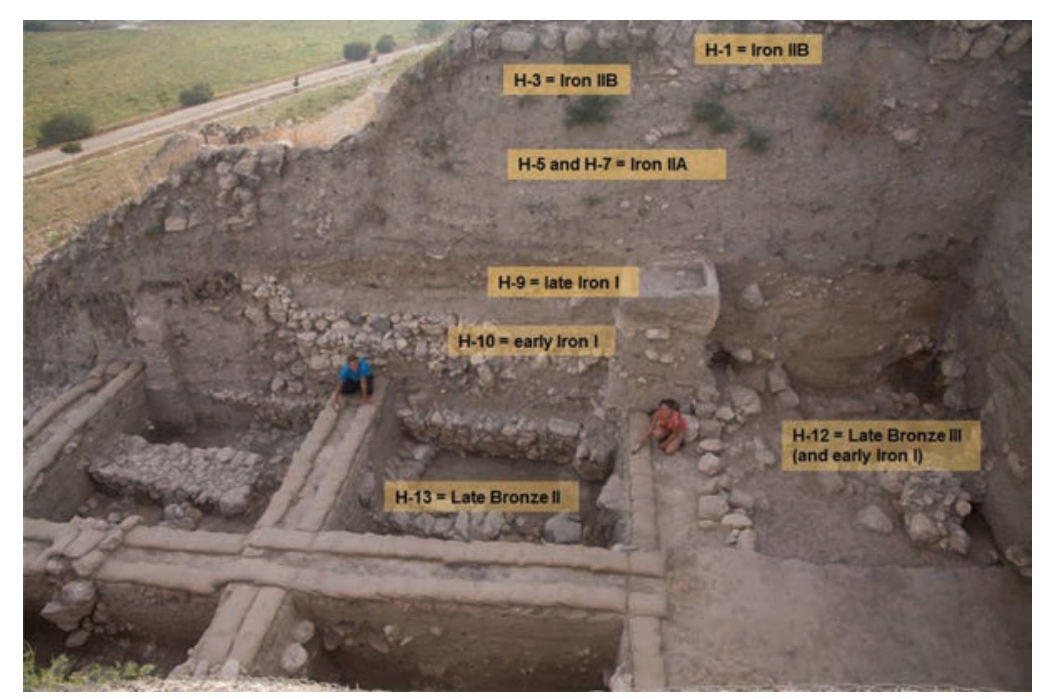

Figure 4 General view of Area H showing the location of some of the archaeological levels mentioned in the text. 


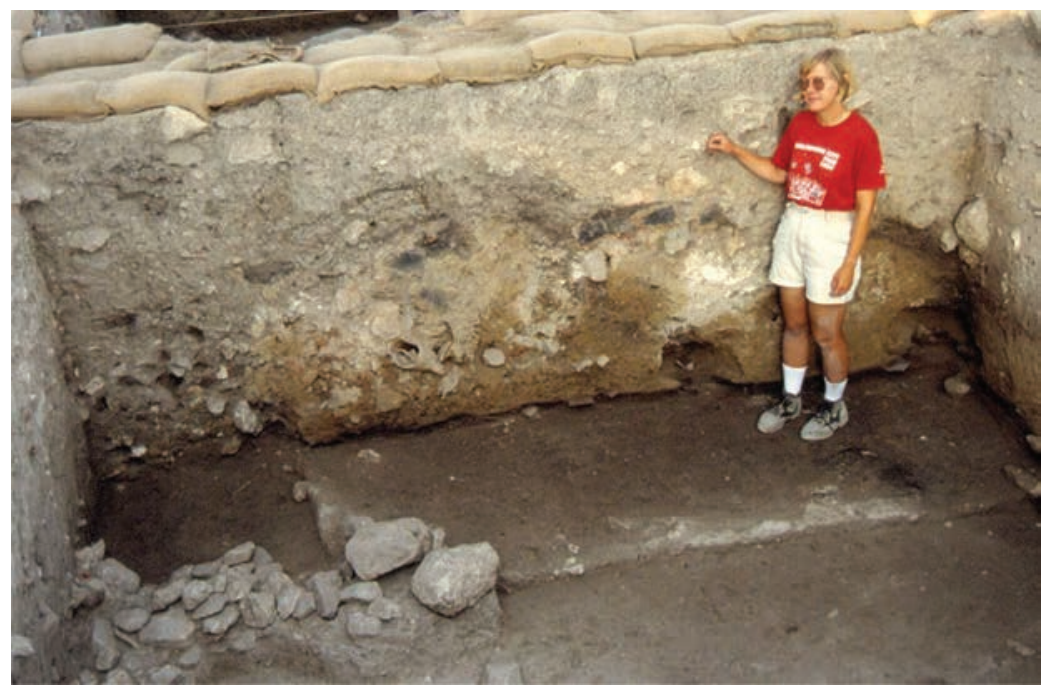

Figure 5 An example of Iron Age destruction layer: Level K-4. Note the $\sim 1$-m accumulation of collapsed debris over the floor.

Table 2 Stratigraphic relationship of the levels discussed in this article; levels destroyed (or partially destroyed) by fire are marked in bold text.

\begin{tabular}{|c|c|c|c|c|c|}
\hline Relative chronology & Area $\mathrm{H}$ & Area $\mathrm{K}$ & Area M & Area $\mathrm{F}$ & University of Chicago Stratum \\
\hline Late Iron IIA & H-5 & & & & VA-IVB \\
\hline Early Iron IIA & H-7 & & & & VB \\
\hline \multirow[t]{2}{*}{ Late Iron I } & H-9 & K-4 & M-4 & & VIA \\
\hline & $\mathrm{H}-10$ & $\mathrm{~K}-5^{\mathrm{a}}$ & & & VIB \\
\hline Early Iron I & H-11 & & & & VIB \\
\hline LB III & $\mathrm{H}-12^{\mathrm{b}}$ & K-6 & M-6 & & VIIA \\
\hline \multirow[t]{2}{*}{ LB IIB } & $\mathrm{H}-13^{\mathrm{a}}$ & $\mathrm{K}-7$ & & & VIIB \\
\hline & & K-8 & & & VIIB \\
\hline LB IIA & & K-9 & & & VIII \\
\hline LB I & & $\mathrm{K}-10^{\mathrm{c}}$ & & F-10 & IX \\
\hline MB III & & $\mathrm{K}-10$ & & & $\mathrm{X}$ \\
\hline
\end{tabular}

aNote that from the point of view of the ceramics, K-5 is contemporary to both H-11 and H-10; similarly, H-13 is contemporary to both K-8 and K-7.

${ }^{b}$ The pottery assemblage of H-12 covers also a portion of the early Iron I, and therefore it overlaps with K-5 from the point of view of the ceramics.

${ }^{c} \mathrm{~K}-10$ covers the span from the end of the MB III to the end of the LB I.

\section{MATERIALS AND METHODS}

\section{Sampling Strategy}

The strategy employed in sampling materials for dating follows the guidelines given in recent studies on the absolute chronology of the Iron Age in the eastern Mediterranean and southern Levant (Sharon 2001; Sharon et al. 2007; Boaretto 2009; van der Plicht et al. 2009). Two important concepts are added to this set of recommendations. As shown by Toffolo et al. (2012), dates obtained from single short-lived samples found at different locations within the same locus should not be averaged, even if they are contemporary from a stratigraphic point of view. This also implies that single olives or seeds from different depths and positions in the same archaeological context should 
be measured separately and not mixed in order to obtain more material for the measurement. This is so especially in layers that did not terminate in a large conflagration. Also, archaeological layers may represent long periods of time. Considering that the relationship between single samples is often unknown (i.e. they could have been deposited in different events in the history of a given layer), where possible we preferred to work with clusters of charred seeds (to differ from single items). Another advantage of this strategy is that clusters allow repeating the measurements on the same sample, thus reducing the standard deviation error of the dates. This is essential when dealing with cases such as the debated Iron I/II transition (Mazar and Bronk Ramsey 2008; Finkelstein and Piasetzky 2010a), in which the difference of opinions is limited to a few decades.

Contexts that yielded good dating material were carefully screened. At Megiddo, loci that can be affiliated stratigraphically are labeled either $\mathrm{F}$ or $\mathrm{A}$, with the former representing habitation contexts and the latter standing for less secure settings. Only $\mathrm{F}$ loci were chosen for ${ }^{14} \mathrm{C}$ dating and thus for the Bayesian models presented here (they make $20-25 \%$ of the loci per excavation season). These are therefore primary deposition locations, which are safely assigned stratigraphically. Examples of such contexts are floors, occupational debris, and destruction layers. They include well-defined ceramic assemblages, which create the link between relative and absolute chronologies. Destruction layers are especially important, as complete ceramic vessels and clusters of charred olive pits or seeds are found buried under thick collapse debris that represents a short event at the very end of a given level.

\section{Radiocarbon Dating}

Charred seeds were pretreated with an acid-base-acid (ABA) procedure to remove all the contaminants, following the methods of Yizhaq et al. (2005) and Rebollo et al. (2008). The purity of the charcoal was checked by means of FTIR spectrometry prior to oxidation in vacuum with $\mathrm{CuO}$ at $900^{\circ} \mathrm{C}$ and for the preparation as graphite. ${ }^{14} \mathrm{C}$ determination was carried out with accelerator mass spectrometry (AMS). The amount of carbon obtained was enough for the AMS measurements. ${ }^{14} \mathrm{C}$ ages are reported in conventional ${ }^{14} \mathrm{C}$ years before present (BP) following the international convention (Stuiver and Polach 1977). All calculated ${ }^{14} \mathrm{C}$ ages have been corrected for isotopic fractionation based on the stable carbon isotope ratio $\left(\delta^{13} \mathrm{C}\right.$ value). Calibrated ages in calendar years have been obtained from the calibration tables of Reimer et al. (2009) using OxCal v 4.1.7 (Bronk Ramsey 2009).

\section{Bayesian Modeling}

${ }^{14} \mathrm{C}$ dates were analyzed with Bayesian statistics using OxCal v 4.1.7 (Bronk Ramsey 2009) in order to build an absolute chronological sequence. Modeling was first done for each excavation area separately following the same methodology with adaptations to the area's stratigraphy, relation between the loci, relation between samples, and absence of data for certain levels. Dates from the same level were grouped as contiguous phases organized in a sequence, according to the stratigraphic information. In some cases, results of a given level were ordered stratigraphically according to loci (i.e. dates were grouped as a sequence). If a level had not provided material for ${ }^{14} \mathrm{C}$ dating, gaps in the main sequence were added to indicate this lack of data. Control over the stratigraphic sequence in different excavation areas, and association to a cultural period based on ceramic typology considerations, allowed comparisons between phases and transitions in different locations at the site. All calibrated ranges within probability distributions are given with $\pm 1 \sigma$ ranges (i.e. $68.2 \%$ probability), unless otherwise specified. 


\section{RESULTS}

${ }^{14} \mathrm{C}$ measurements with related calibrated ranges and context information are presented in Table 3. Thus far, unpublished, new measurements (marked with bold text) were grouped with dates from previous studies (Boaretto et al. 2005; Finkelstein et al. 2006; Sharon et al. 2007; Finkelstein and Piasetzky 2007; Gilboa et al. 2013) in order to cover the whole stratigraphic sequence from the Middle Bronze (hereafter MB)-LB transition through to the late Iron IIA. We refer to those publications also regarding the exclusion of some of the dates from the Bayesian analysis as outliers, and to the different AMS laboratories where the measurements were carried out. The total number of measurements considered here is 190 on 78 short-lived samples, with standard deviations as low as $\pm 15 \mathrm{yr}$ BP after combining multiple independent measurements of the same samples. All the combined dates passed the $\chi^{2}$ test.

In the following, three Bayesian models are presented, one for each of the excavation areas that feature multiple relative chronology phases (based on ceramic typology) - areas $\mathrm{H}$ and $\mathrm{K}$-and a general one that encompasses the entire chronological sequence of Megiddo from the MB-LB transition to the end of the late Iron IIA (with additional dates from areas M and F; it was impossible to build independent models for these areas since only two levels in the former and one in the latter provided samples for dating and as these samples gave single dates). Note that in a model for a single area, stratigraphy is the main parameter that imposes the sequence on the ${ }^{14} \mathrm{C}$ dates, while in the general model, which puts together more than one area, typology imposes contemporaneity between levels in different areas. This distinction defines also the nature of the outlier (stratigraphic vs. typological).

\section{Model H: Area H}

Model H (Tables 4-5; Figure 6) shows the absolute dates for Area H. The dates are grouped in a sequence of contiguous phases (i.e. one starts as the previous one ends) except for Level H-7, which is surrounded by "gaps" left for levels $\mathrm{H}-8$ and $\mathrm{H}-6$, for which no ${ }^{14} \mathrm{C}$ determinations are available. In both cases, a period of $20 \pm 10 \mathrm{yr}$ was entered as an estimation, as both feature relatively thin accumulations of debris; also note that according to the ${ }^{14} \mathrm{C}$ model for the Iron Age (Finkelstein and Piasetzky 2010a), the entire Iron IIA, which is represented in Area $\mathrm{H}$ by four levels, two of them quite substantial, lasted for less than $150 \mathrm{yr}$. The ceramic assemblage of Level H-12 covers both the LB III and the beginning of the early Iron I; hence, this layer seems to include the period of Level K-6 plus a certain period of time later than the demise of the latter. Indeed, this level is represented by a thick, $\sim 50-\mathrm{cm}$ accumulation of living surfaces. Levels H-13 and H-5, the first and last in Area $\mathrm{H}$ for which we have radiometric results, can be given only the end and start dates, respectively. The dates of Level H-9 are organized within a sequence of two phases, a destruction event that marks the very end of this layer and the occupational period prior to this event. Note that Level H-7 is represented by one sample only.

The Area $\mathrm{H}$ plot shows an overall agreement index of $75 \%$ between the data and the model, with two outliers determined by the model. The agreement of the two samples from Level H-13 with Model $\mathrm{H}$ should be considered cautiously since they are not limited by dates from an earlier level. Still, RTK-6772 (Level H-13) may be too old. This sample indeed remains an outlier also compared to the dates for levels K-8 and K-7, which cover the same relative chronology slot, the LB IIB (Table 3). Note that this sample does not represent a cluster. RTK-6511 was taken from a textile used in order to wrap a silver bundle, which was part of a jewelry hoard found in Level H-11. This piece of cloth seems to have been used for a long period of time, creating a sort of "old textile" effect. 
Absolute Chronology of Megiddo in the Late Bronze \& Early Iron

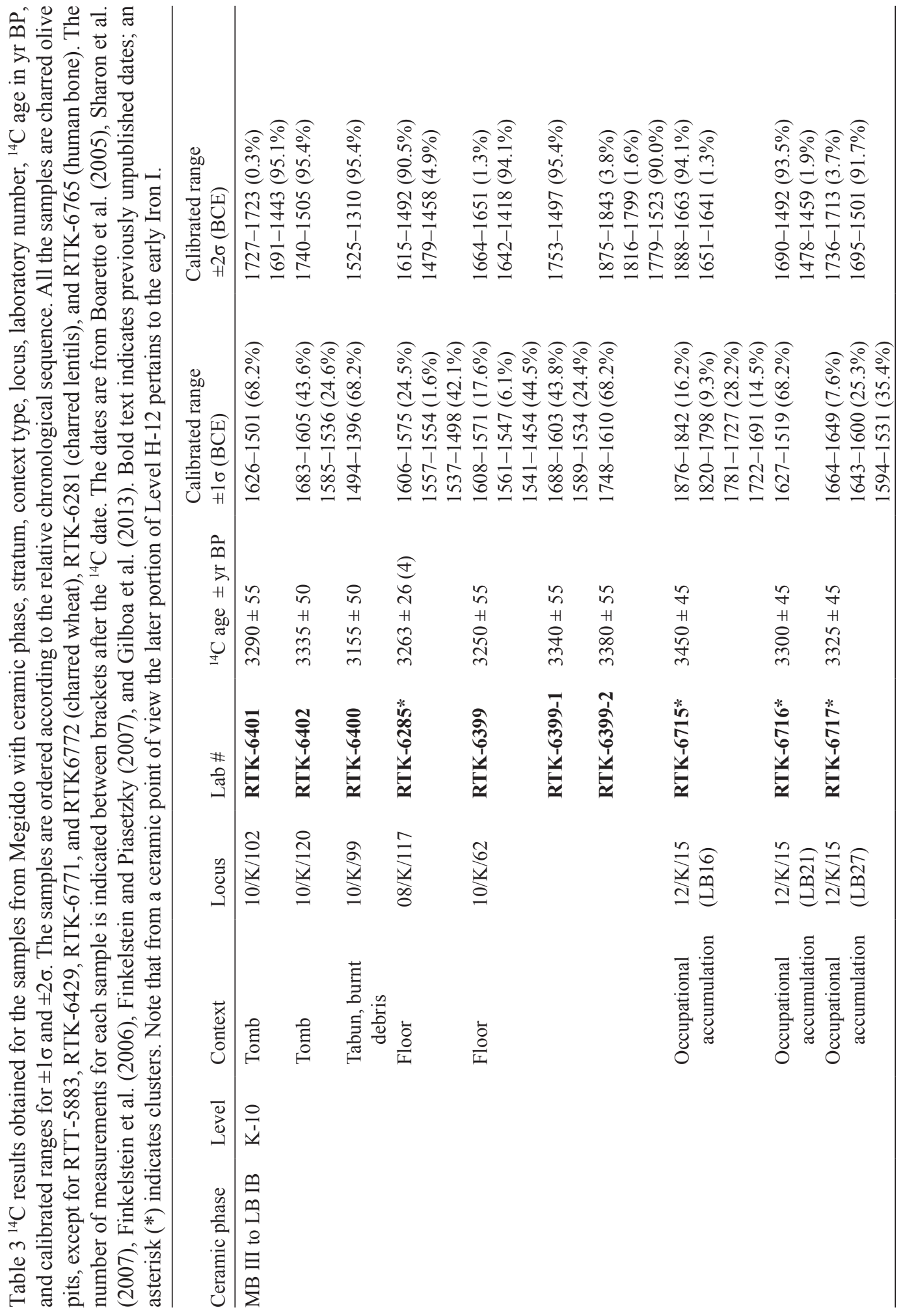




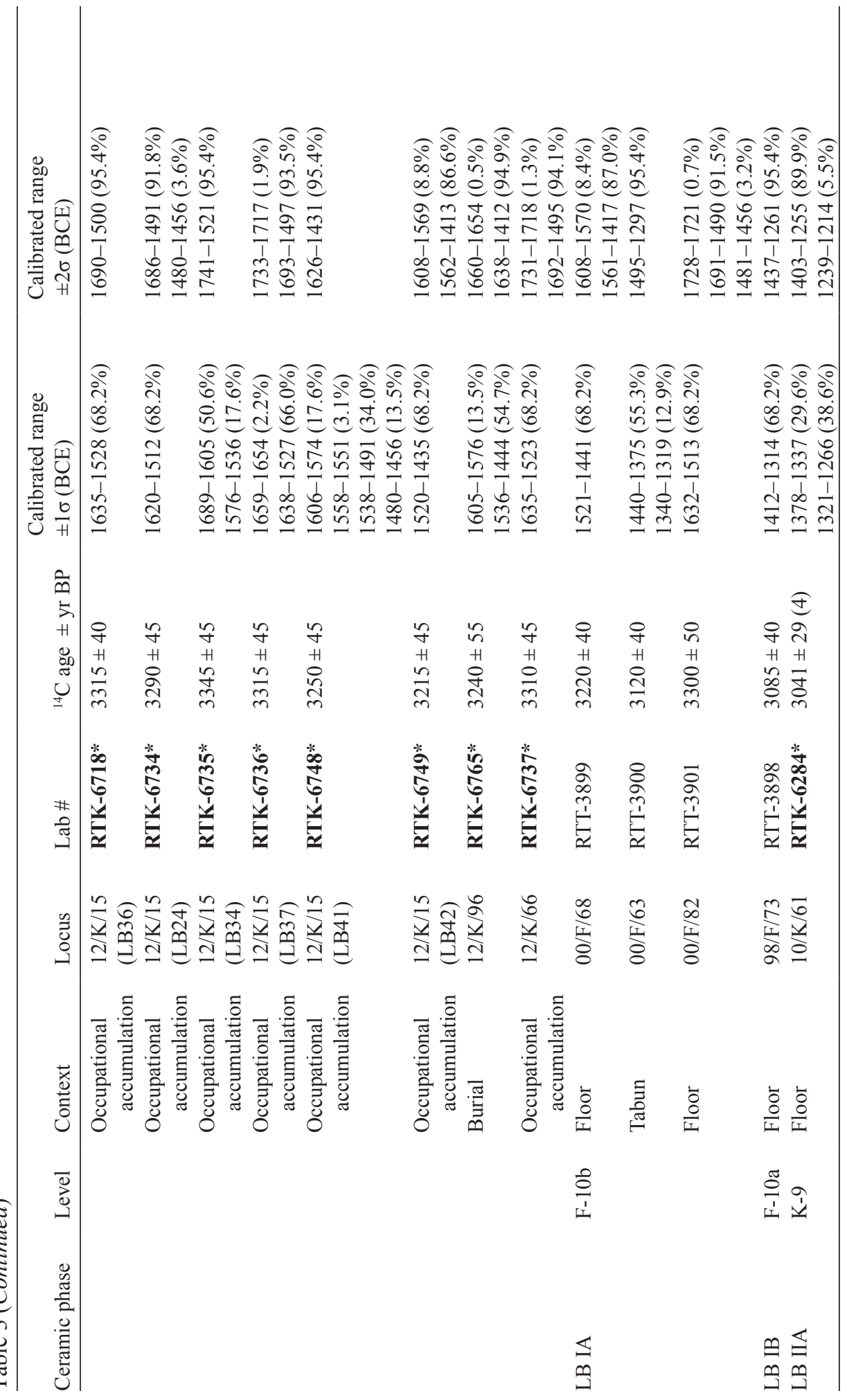




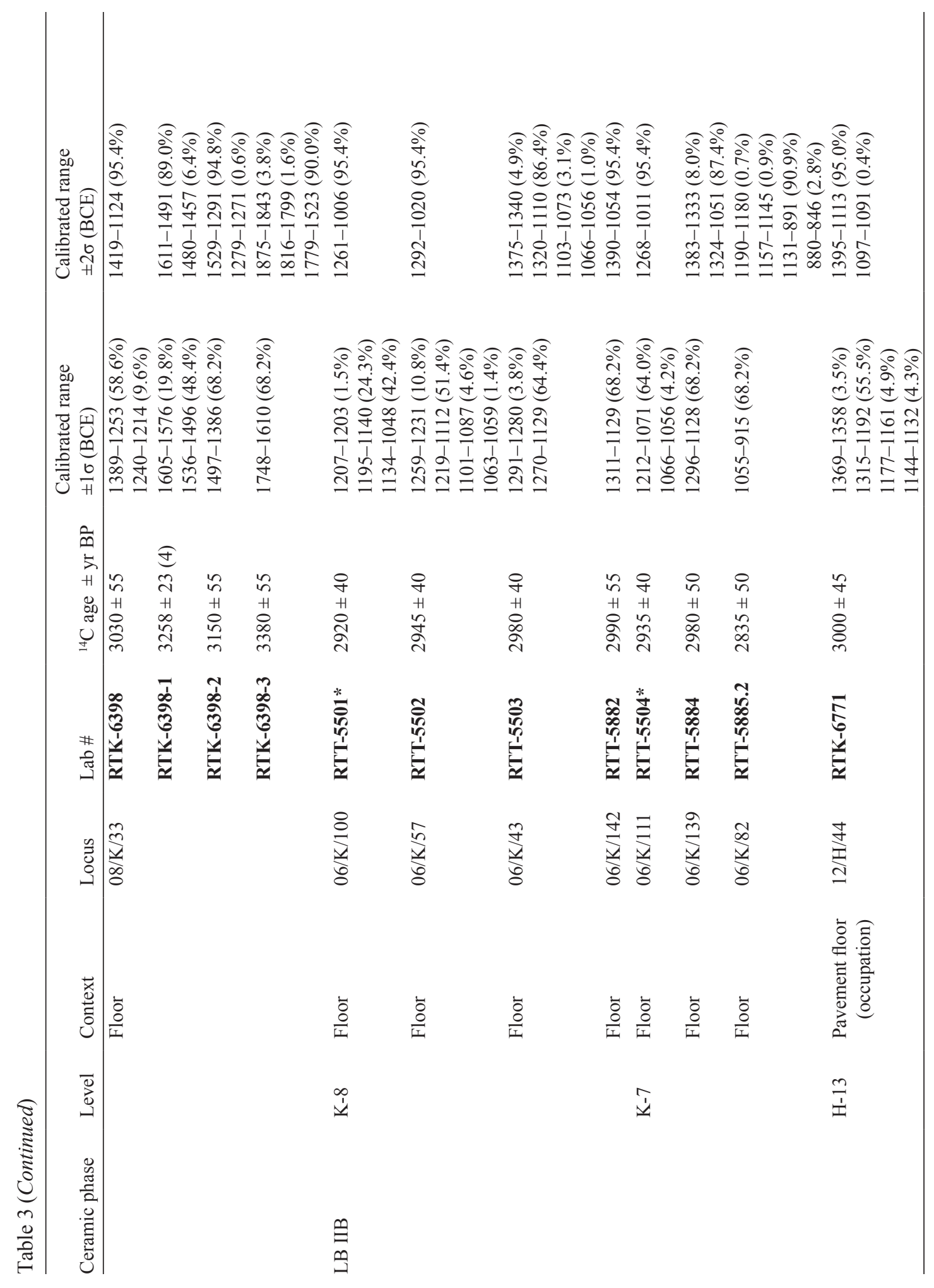




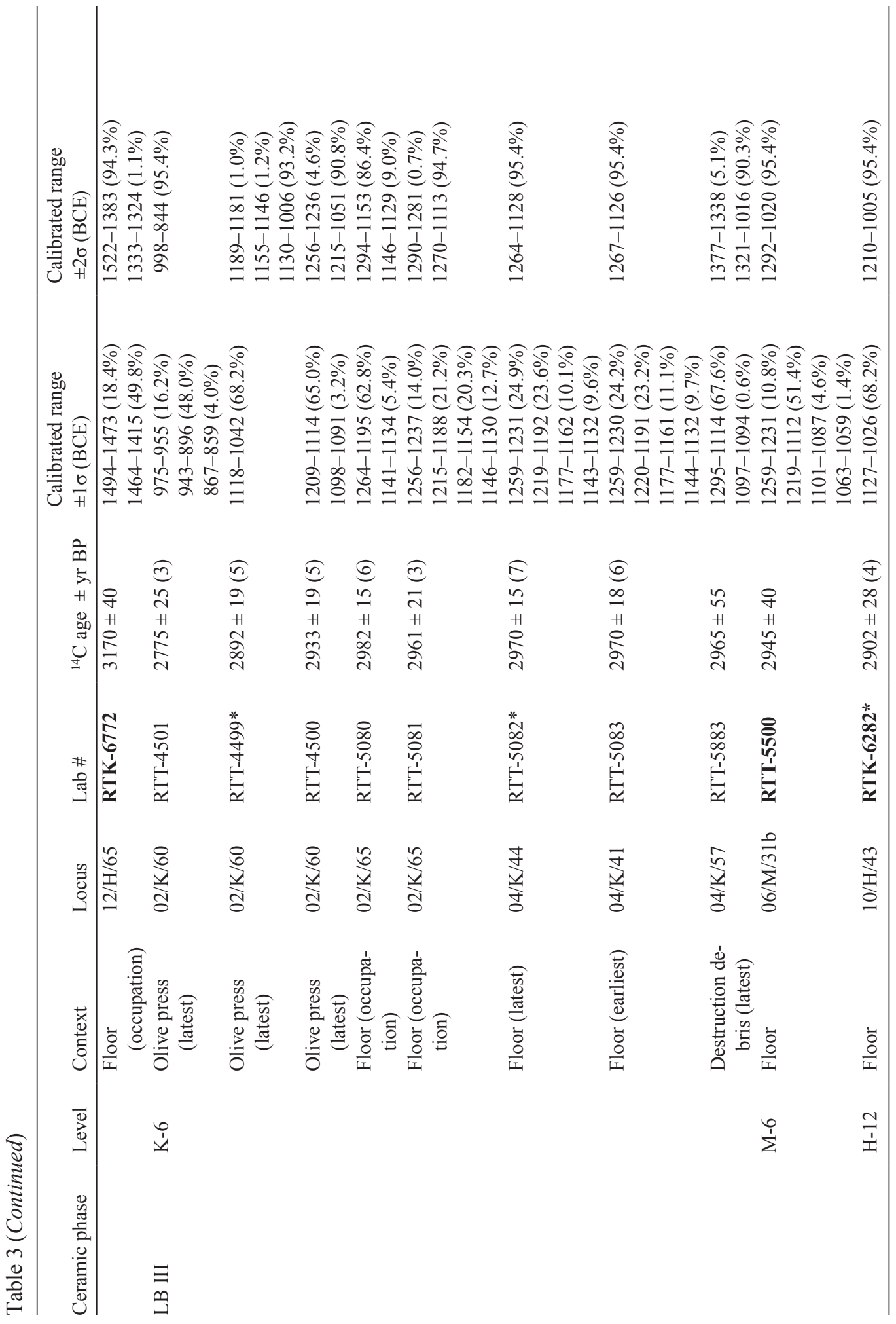




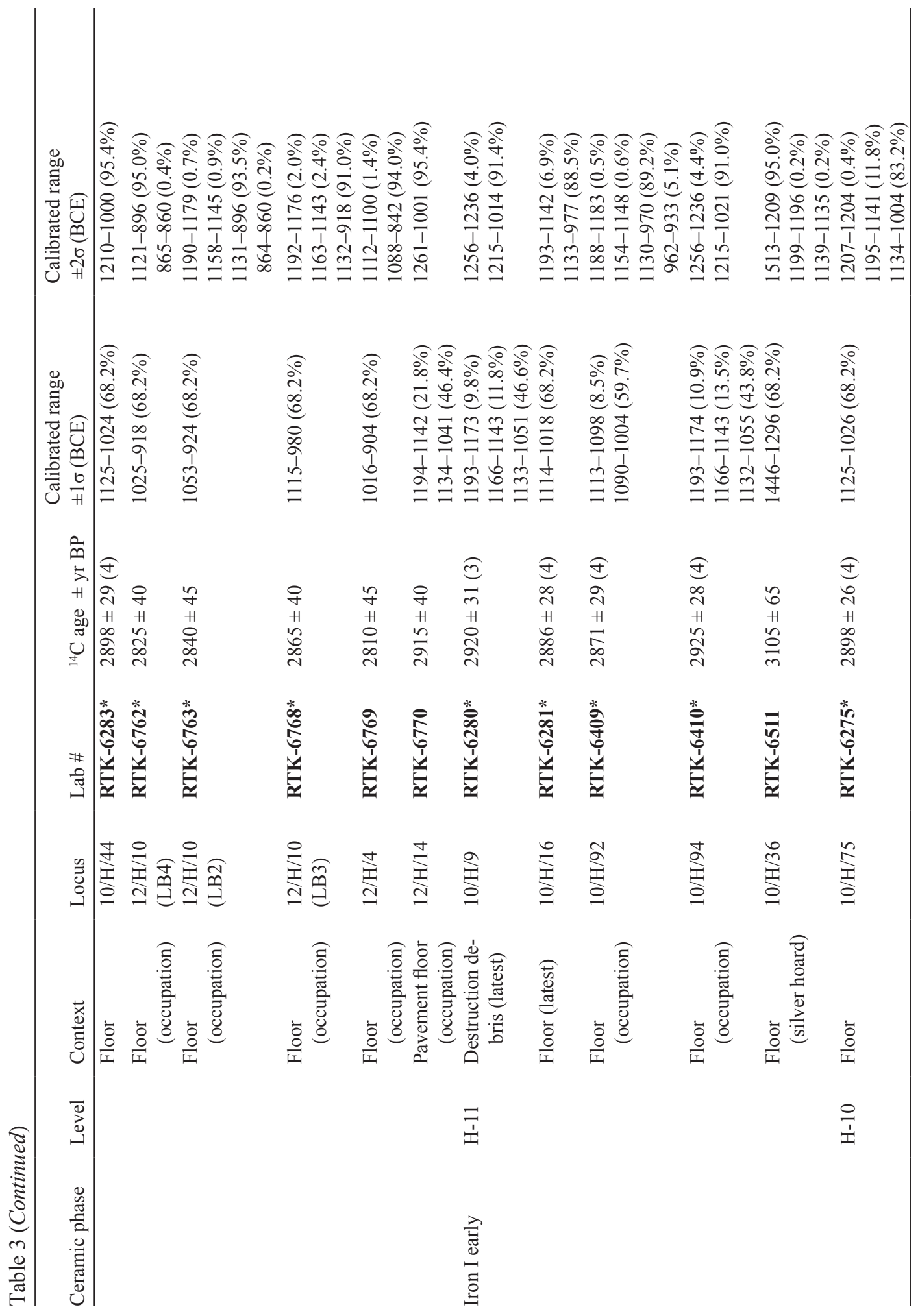




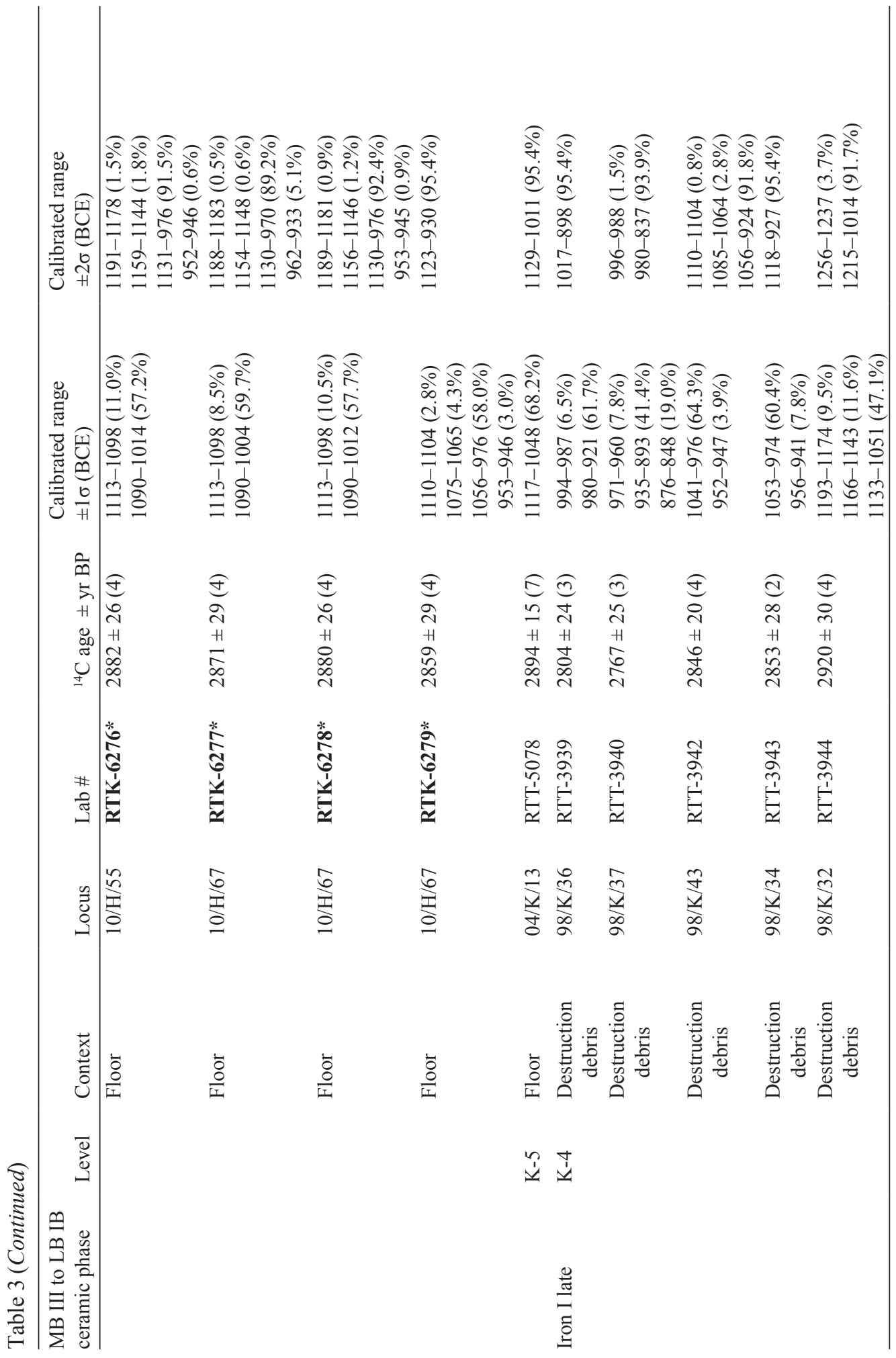




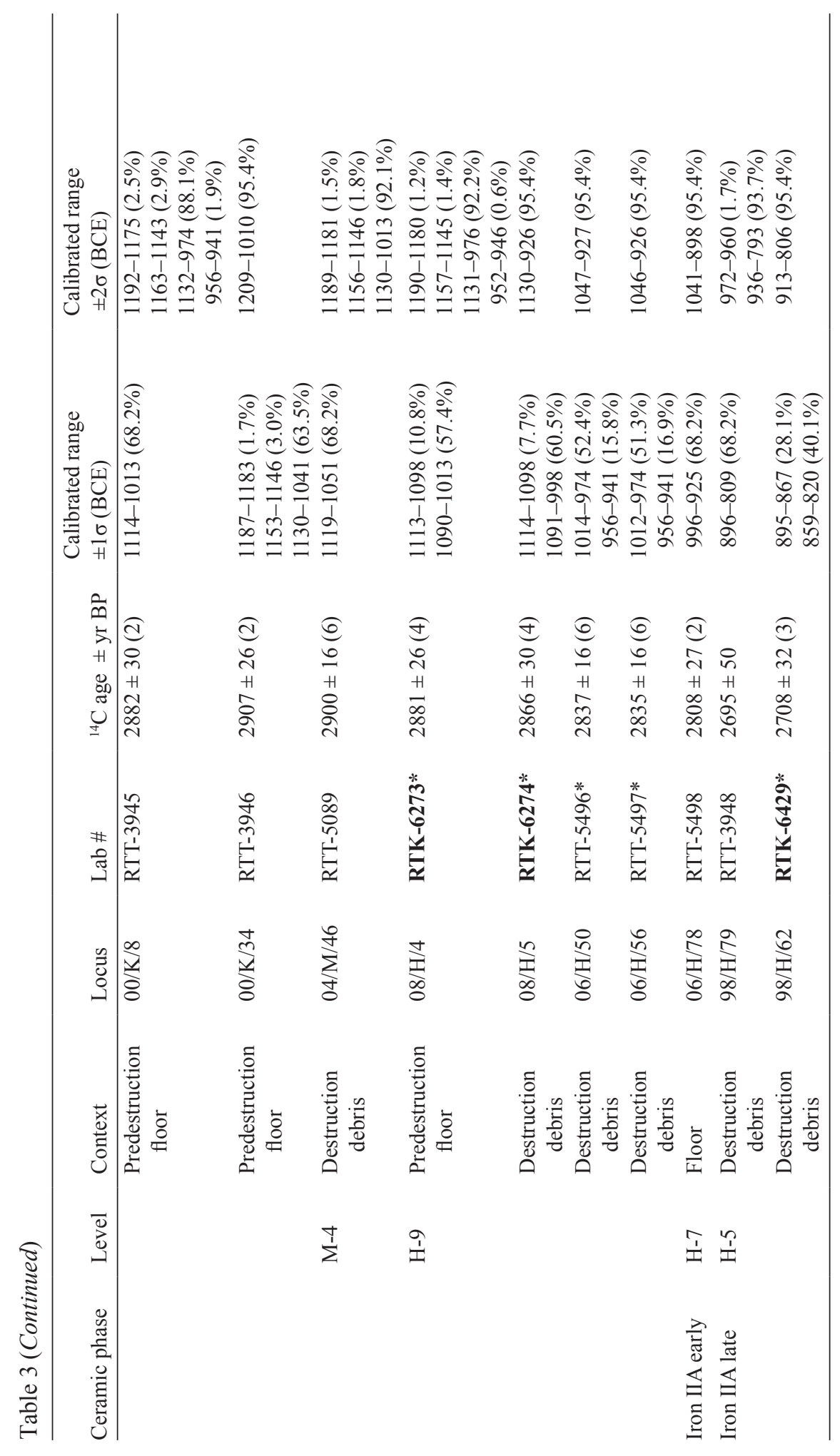


Table 4 Megiddo chronology, transitions between levels in areas $\mathrm{H}$ and $\mathrm{K}$ (based on models $\mathrm{H}$ and $\mathrm{K}, 68.2 \%$ probability).

\begin{tabular}{lllll}
\hline H transitions & Absolute dates & Relative chronology & K transitions & Absolute dates \\
\hline H-10/H-9 & $1035-1010$ & Early to late Iron I & K-5/K-4 & $1110-1060$ \\
H-11/H-10 & $1060-1025$ & Within early Iron I & & \\
H-12/H-11 & $1095-1045$ & Within early Iron I & & \\
& & LB III/ early Iron I & K-6/K-5 & $1135-1090$ \\
H-13/H-12 & $1125-1070$ & LB IIB/III & K-7/K-6 & $1185-1135$ \\
& & Within LB II & K-8/K-7 & $1245-1170$ \\
& & LB IIA/IIB & K-9/K-8 & $1290-1210$ \\
& & LB I/IIA & K-10/K-9 & $1560-1505$ \\
\hline
\end{tabular}

Two additional dates show low agreement, namely RTK-6762 and RTK-6769, both from Level H-12. They are slightly too young compared to other $\mathrm{H}-12$ samples, and this is partly explained by the fact that the $\mathrm{H}-12$ dates are grouped in a phase. In OxCal terms, a phase is a group of dates with no internal ordering. In the Bayesian model, this will result in the smallest portion of time allowed by the probability distributions of the dates included in the phase. Therefore, samples that are slightly older or younger (as in this case) than the portion determined by the model will show low agreement. At this stage, there is no explanation for such a wide probability distribution for this level. Note that the exclusion of these two dates from the model would not change the range of the transitions between the different levels.

The early Iron I is represented in Area H by three layers (the later days of Level H-12 and levels H-11 and H-10). The end of Level H-9, which marks one side of the Iron I/II transition, is set at 1015-985 BCE. As discussed previously, it is impossible to calculate the actual transition, as there are no ${ }^{14} \mathrm{C}$ dates for Level $\mathrm{H}-8$, which represents the very beginning of the Iron IIA. The latest excavation season (2012) seems to point to a postdestruction occupational phase at the very end of the late Iron I in another area at Megiddo (Level Q-6 from Area Q), for which there are no ${ }^{14} \mathrm{C}$ dates. This phenomenon of postdestruction very late Iron I layers is also known in other sites in the north, such as Yoqne'am and Tel Kinneret (Arie 2011:365-70). Taking both factors (lack of dates for Level H-8 and the information regarding Level Q-6) into consideration, another gap of $20 \pm$ $10 \mathrm{yr}$ was entered, which represents the postdestruction late Iron I occupational phase. This phase should start after the end of Level H-9 (range: 1015-985), thus a terminus post quem (TPQ1 in

Table 5 Megiddo chronology, transitions between the ceramic phases (based on models $\mathrm{H}, \mathrm{K}$, and General, $68.2 \%$ probability); TPQ = terminus post quem.

\begin{tabular}{lccl}
\hline Transition & Model H $($ Area H) & Model K (Area K) & General model \\
\hline Iron I/IIA & $985-935($ with TPQ) & $988-984(2.3 \%)^{\mathrm{a}}$ & $985-935$ (with TPQ) \\
& & $976-901(65.9 \%)^{\mathrm{a}}$ & \\
Early Iron I/late Iron I & $1035-1010$ & $1110-1060$ & $1065-1025$ \\
LB III/Iron I & $1095-1045$ & $1135-1090$ & $1100-1060$ \\
LB IIB/III & $1125-1070$ & $1185-1135$ & $1180-1135$ \\
LB IIA/B & & $1290-1210$ & $1290-1200$ \\
LB I/IIA & & $1560-1505$ & $1480-1475(2.6 \%)$ \\
& & & $1435-1375(65.6 \%)$ \\
\hline
\end{tabular}

${ }^{a}$ End boundary of Level K-4. 


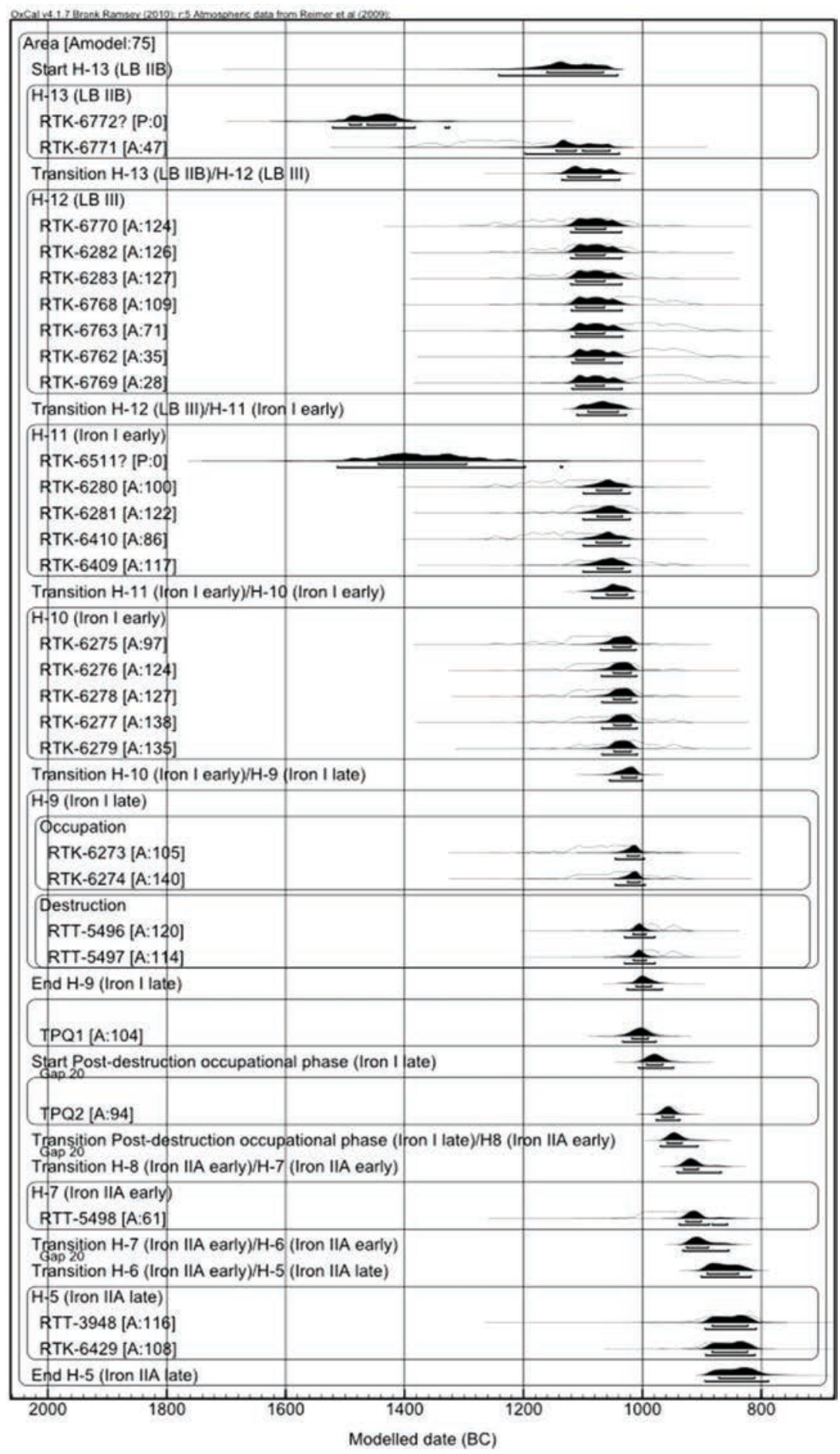

Figure 6 Bayesian model of Area $\mathrm{H}$ based on stratigraphic information. Note that all the levels are represented by OxCal phases, except for $\mathrm{H}-9$, which is a sequence of two phases ("occupation" and "destruction"). 
Model H) of $1000 \pm 15$ was entered as a threshold for its beginning. Similarly, another terminus post quem (TPQ2 in Model H) was entered to test within which range the important Iron I/II transition can take place (Transition Boundary "Post-destruction occupational phase/H- 8 " in Model H). The lowest TPQ2 allowed by the model is set at $950 \pm 10$, which results in a transition at 960-935 BCE (Table 5). Considering the end boundary for Level H-9, the transition Iron I/II could fall anywhere between 985 and 935 BCE.

\section{Model K: Area K}

The absolute sequence for Area $\mathrm{K}$ is shown in Model K (Tables 4-5; Figure 7). The dates are grouped in contiguous phases. For levels K-6 and K-4, the samples are further subdivided between those representing the history of occupation and those standing for the end event, that is, the destruction. One particular locus from Level K-10 $(12 / \mathrm{K} / 15)$ was characterized by a superimposition of living surfaces, some of them bearing clusters of charred olive pits. The results for this locus were put in stratigraphic order according to the different elevations; the entire set is contemporary to all other samples from this level. Consisting of several architectural phases and a thick accumulation of living surfaces, Level K-9 probably represents a relatively long period of time. Level K-5 features fragmentary remains and is represented here by a single sample.

The agreement between the data and the model is $73 \%$, but this result was achieved only after excluding from the plot five dates identified as outliers by the model, namely RTK-6399-2 and RTK-6715 (K-10), RTK-6398-3 (K-9), RTT-5885.2 (K-7), and RTT-4501 (K-6). RTK-6715 and RTK-6399-2 appear to be too old compared with other dates of K-10. Sample RTK-6398 comprised a few charred olive pits found in the same location but not in a cluster; hence, measurements were not averaged. RTK-6398-3 is an outlier because the date is too old even for the earlier levels: K-10 and F-10 (Table 3). RTT-5885.2 provides a date younger than expected for Level K-7 of the LB IIB. This is probably because of the problematic stratigraphic affiliation of this sample: it was collected from a floor identified during the removal of a baulk, with no reliable Level K-7 floors found to its sides (Table 3). The last outlier (RTT-4501) is part of a concentration of charred olive pits found inside an olive press. This installation yielded two other assemblages, RTT-4499 and RTT-4500, which show a much older age, consistent with all other K-6 dates (Table 5). Therefore, RTT-4501 is identified as an outlier.

Three samples show low agreement with the model: RTK-6749 and RTK-6400 from Level K-10 and RTT-4499 from Level K-6 are somewhat younger compared to other dates from these levels. However, even if they would have been excluded from the plot as outliers, the transitions determined by the Bayesian analysis would not change.

It is impossible to establish the transition between the MB III and the LB IA, considering that Level K-10 covers the end of the former and the beginning of the latter. The overlap in the results between LB II and LB III (Table 3) is created at least partly due to the Late Bronze age plateau within the calibration curve ( 1300-1150 BCE). The Bayesian model reduces this overlap.

\section{General Model}

For the construction of a general absolute sequence for the site of Megiddo (General Model - Table 5; Figures 8 and S1, online Supplemental file), it was decided to add dates from areas F (LB I) and M (LB III and late Iron I). This plot covers the entire LB-to-Iron IIA sequence, with an agreement of $64 \%$ between the data and the model, and two new outliers (in addition to the seven mentioned previously). The samples excluded by the model are RTK-6749 from Level K-10 and RTK-6398-1 from Level K-9 (too old to be located after the F-10a date). Some differences in the 


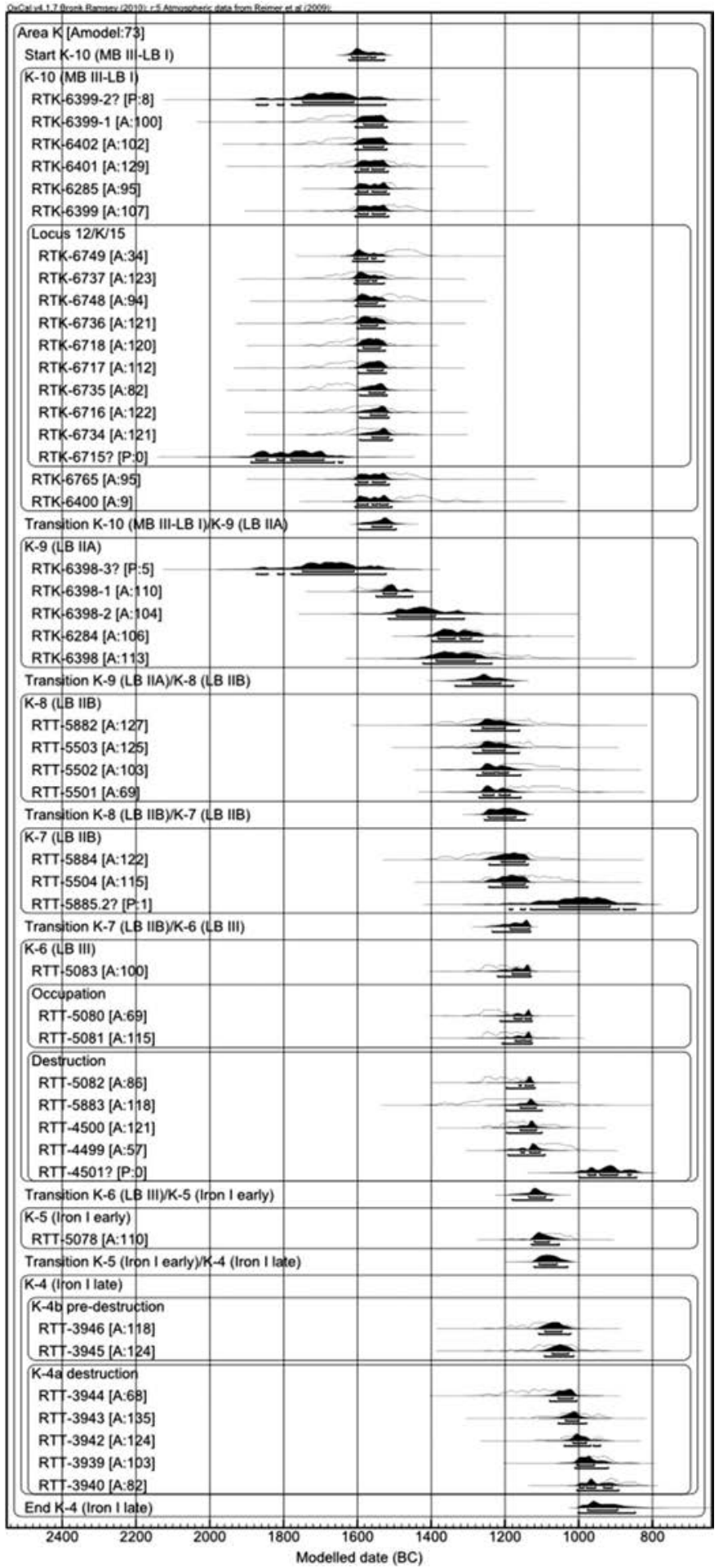

Figure 7 Bayesian model of Area $\mathrm{K}$ based on stratigraphic information. Note that all the levels are represented by OxCal phases, except for levels K-6 and K-4, which are a sequence of two phases each ("occupation" and "destruction" for K-6 and "predestruction" and "destruction" for K-4). 
Figure 8 Schematic view of the transitions $(68.2 \%$ probability) in the different excavation areas and in the general model (E: early; L: late). Note that it is not possible to calculate the range for the Iron I L/IIA transition in Area $\mathrm{K}$ (blank rectangle); the rectangle filled with a grid marks the range of the End Boundary of Level K-4. Timeline is in years BCE.

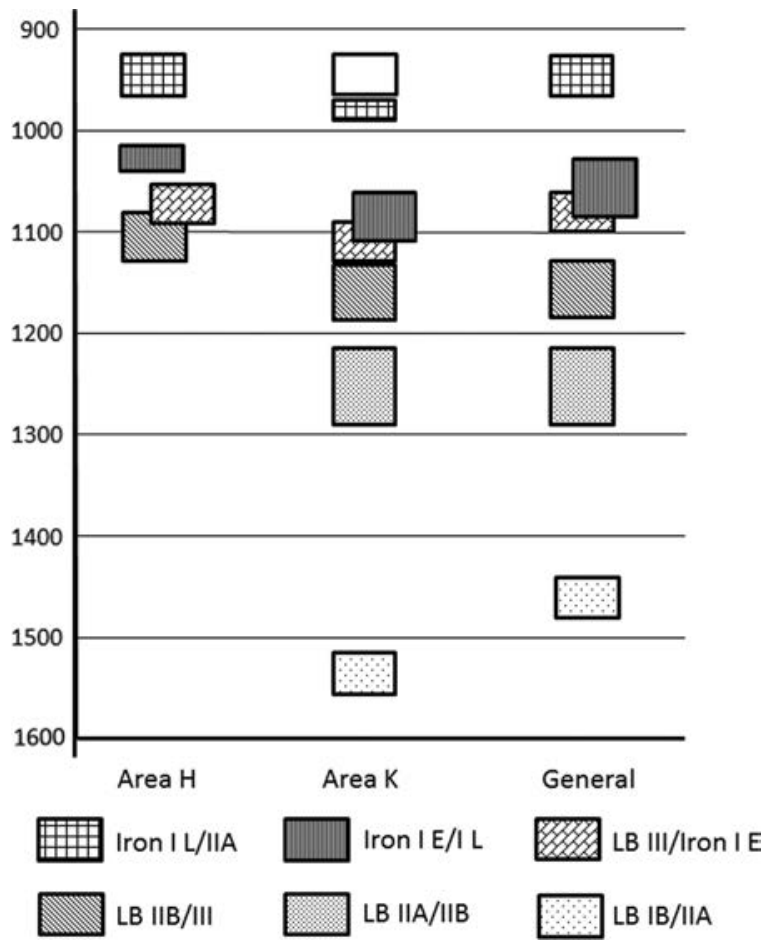

stratigraphy/relative chronology between areas should be noted: (1) Level K-10 covers both the end of the MB and the LB I, while Level F-10 covers the LB I only; (2) Level H-12 starts parallel to levels K-6 and M-6 of the LB III, but continues into the early Iron I (in other words, habitation in Area $\mathrm{H}$ continued after a partial destruction in areas $\mathrm{K}$ and $\mathrm{M}$ ). Note that this situation is impossible to express in OxCal terms.

The LB transitions are similar to the ones in Model K, except for the LB IB/IIA. This is explained by the presence of the F-10a date, which is younger compared to most of the K-10 dates, and therefore lowers the result. With this addition, sample RTK-6400, which showed poor agreement in Model B, is now in much better agreement with the model. Samples RTK-6762 and RTK-6769 of Level H-12 still have low agreement as in Model $\mathrm{H}$, and this is also the case for RTK-6763. The same holds true for RTT-3940 (Level K-4), which is too young compared to the dates of H-9; still it has not been excluded from the model.

Using the same methodology deployed for Model $\mathrm{H}$, possible location of the Iron I/II transition was tested by adding a gap for the postdestruction occupational phase identified in Area Q and the two TPQ. The only difference lies in the range of TPQ2, which is now $980 \pm 10$. This is the lowest TPQ allowed by the model, taking into account that some of the dates of Level K-4 are younger compared to the dates of Level H-9, and therefore tend to "push down" the end of the Iron I destruction event (note that the archaeological evidence, especially the pottery assemblages, does not suggest a difference in date between the end of levels K-4 and H-9). Nevertheless, the resulting transition occurs at 985-935 BCE, as in the case of Model H.

\section{DISCUSSION}

Scholars debated the circumstances and date of the transition from the Middle Bronze to the Late Bronze in Canaan: according to some it occurred at the very beginning of the 18th Dynasty in Egypt, 
$\sim 1530 \mathrm{BCE}$, as a result of Egyptian punitive campaigns after the expulsion of the Hyksos from Egypt, causing severe destructions throughout the southern Levant. According to others, it was a gradual process that, at least in certain regions of the Levant (including the Jezreel Valley), ended only with the first military campaign of Thutmose III to Canaan and the beginning of Egyptian direct rule there in 1450 BCE (e.g. Kenyon 1960:194-8; Seger 1975; Redford 1979; Weinstein 1981; Dever 1987; Bietak 1991; Burke 2010). For now, the Megiddo data cannot resolve this issue because (a) we do not have yet dates for the end phases of the Middle Bronze and (b) in Area K the transition in the pottery tradition occurred within the life of Level K-10. The date of transition from the LB I to the LB IIA (levels K-10/9) may provide a clue, though the results are inconclusive. The model for Area K puts this transition close to $1500 \mathrm{BCE}$, excluding an $\mathrm{MB} / \mathrm{LB}$ transition in the early 15th century; the model for the entire site (influenced by the results of Area F; Figure 8) puts the LB I/IIA transition later and hence allows both alternatives for the MB/LB transition. The reason for this discrepancy between the models may lie in a short occupational gap in Area K in the late LB I (Level K-10); in other words, a late LB I occupation phase in Area F is missing in Area K. The late LB I nature of the assemblage in Area F may also be hinted at by an Egyptian import that best fits in the later days of Thutmose III (his sole reign) or even later (Martin 2009). Such an inconsistency (continuity in one sector and a gap in another) may happen at a large site such as Megiddo. Another possibility is that Level K-9, a long-lived phase, in fact started already in the later days of the LB I, and that this is not clearly seen in its pottery assemblage because it represents its end days. In any event, a LB I/IIA transition in the late 16th century, as ostensibly emerging from the K model, is too early from the Egyptian historical perspective, even if one were to begin the LB I at the very beginning of the 18th Dynasty ( $1530 \mathrm{BCE})$. One way or the other, at this point the data are not sufficient for a definite answer regarding the date of both this and the MB/LB transitions.

The transition from the LB IIA to the LB IIB (levels K-9/8; Figure 8) falls within the 13th century $\mathrm{BCE}$. This is somewhat too late for the traditional chronological scheme, which places this transition at 1300 BCE (e.g. Mazar 1997:238, 242). Specifically at Megiddo, however, a transition sometime after $1250 \mathrm{BCE}$ is suggested by the Aegean pottery evidence, based on the latest datable material from Stratum VIII (LB IIA) of the Oriental Institute of Chicago excavations (Stockhammer 2011). The LB IIB/III transition (levels K-7/6 and H-13/12; Figure 8) falls during the 12th century BCE, which accords well with the historical changeover in Egypt from the 19th to the 20th dynasties. A transition in the first quarter of the 12th century BCE is well established by the rich, well-datable ceramic assemblages (Aegean, Cypriot, Egyptian, and Levantine type pottery) from Megiddo (Martin 2013) and nearby Beth-Shean (Martin 2011:140-2). The LB III/Iron I transition (levels K-6/5 and $\mathrm{H}-12 / 11$; Figure 8) is difficult to fix because of the fact that pottery-wise Level H-12 starts in the LB III and continues into the early days of the Iron I. This issue goes far beyond the ${ }^{14} \mathrm{C}$ evidence and calls for a detailed pottery and historical discussion. It will therefore be dealt with in another place.

The early/late Iron I transition (levels K-5/4 and H-10/9; Figure 8) provides slightly different results in the two Megiddo excavation areas. Since only a single date is available for Level K-5, and as the stratigraphy is denser (with more data on both the pottery assemblages and ${ }^{14} \mathrm{C}$ results) in Area $\mathrm{H}$, we would prefer the date provided by the latter, sometime in the second half of the 11th century BCE. The disputed transition from the late Iron I to the Iron IIA (Sharon et al. 2007; Mazar and Bronk Ramsey 2008; Finkelstein and Piasetzky 2010b) falls in the range 985-935 BCE (Figure 8), meaning that it cannot be decided according to the Megiddo data. Note that the gap between the two camps has now narrowed to a few decades, 970-940 BCE (Finkelstein and Piasetzky 2011; Mazar 2011). 


\section{CONCLUSIONS}

The detailed ${ }^{14} \mathrm{C}$ data for the Late Bronze and Iron ages at Megiddo - unparalleled in any other site in the Levant - shed light on the cultural processes that took place at Megiddo and beyond in the critical centuries between roughly 1600/1500 and 800 BCE. They provide the first detailed, ${ }^{14} \mathrm{C}$-based chronological system for the Late Bronze Age in the Levant. The Megiddo model shows the advantage of working in a site of continuous habitation with good control over the pottery assemblages. It also shows the benefit of a site with more than one area of excavation, which enables rechecking delicate chronological issues and engaging in intrasite analysis. Future seasons at Megiddo are expected to extend the model to the Middle Bronze and Early Bronze ages and to produce more ${ }^{14} \mathrm{C}$ determinations for the early Iron IIA in Area Q, and thus provide a full sequence for the Bronze and Iron Age, between $\sim 3000$ and 750 BCE.

\section{ACKNOWLEDGMENTS}

The research leading to these results has received funding from the European Research Council under the European Community's Seventh Framework Program (FP7/2007-2013)/ERC grant agreement $n^{\circ}$ 229418. MBT wishes to thank Eugenia Mintz for her help in the preparation of the ${ }^{14} \mathrm{C}$ samples.

\section{REFERENCES}

Arie E. 2006. The Iron Age I pottery: Levels K-5 and K-4 and an intra-site spatial analysis of the pottery from Stratum VIA. In: Finkelstein I, Ussishkin D, Halpern B, editors. Megiddo IV: The 1998-2002 Season. Tel Aviv: Institute of Archaeology of Tel Aviv University. p 191-298.

Arie E. 2011. "In the land of the valley": settlement, social and cultural processes in the Jezreel Valley from the end of the Late Bronze Age to the formation of the monarchy [PhD dissertation]. Tel Aviv: Tel Aviv University.

Arie E. 2013a. Area H: Levels H-9 to H-5. In: Finkelstein I, Ussishkin D, Cline EH, editors. Megiddo V: The 2004-2008 Seasons. Tel Aviv: Institute of Archaeology of Tel Aviv University. p 247-74.

Arie E. 2013b. The Late Bronze III and Iron I pottery: Levels K-6, M-6, M-5, M-4 and H-9. In: Finkelstein I, Ussishkin D, Cline EH, editors. Megiddo V: The 2004-2008 Seasons. Tel Aviv: Institute of Archaeology of Tel Aviv University. p 475-667.

Arie E. 2013c. The Iron IIA pottery. In: Finkelstein I, Ussishkin D, Cline EH, editors. Megiddo V: The 2004-2008 Seasons. Tel Aviv: Institute of Archaeology of Tel Aviv University. p 668-800.

Arie E, Nativ A. 2013. Area K, Part II: Level K-6. In: Finkelstein I, Ussishkin D, Cline EH, editors. Megiddo $V$. The 2004-2008 Seasons. Tel Aviv: Institute of Archaeology of Tel Aviv University. p 165-77.

Bietak M. 1991. Egypt and Canaan during the Middle Bronze Age. Bulletin of the American Schools of Oriental Research 281:27-72.

Boaretto E. 2009. Dating materials in good archaeological contexts: the next challenge for radiocarbon analysis. Radiocarbon 51(1):275-81.

Boaretto E, Jull AJT, Gilboa A, Sharon I. 2005. Dating the Iron Age I/II transition in Israel: first intercom- parison results. Radiocarbon 47(1):39-55.

Boaretto E, Gilboa A, Sharon I. 2009. Radiocarbon dating. In: Gadot Y, Yadin E, editors. Aphek-Antipatris II: The Remains on the Acropolis. Tel Aviv: Institute of Archaeology of Tel Aviv University. p 575-8.

Bronk Ramsey C. 2009. Bayesian analysis of radiocarbon dates. Radiocarbon 51(1):337-60.

Burke AA. 2010. Canaan under siege. The history and archaeology of Egypt's war in Canaan during the early Eighteenth Dynasty. In: Vidal J, editor. Studies on War in the Ancient Near East. Collected Essays on Military History. Münster: Alter Orient und Altes Testament. p 43-66.

Carmi I, Ussishkin D. 2004. ${ }^{14} \mathrm{C}$ dates. In: Ussishkin D, editor. The Renewed Archaeological Excavations at Lachish (1973-1994). Tel Aviv: Institute of Archaeology of Tel Aviv University. p 2508-13.

Davies GI. 1986. Megiddo. Cambridge: Lutterworth Press.

Dever WG. 1987. The Middle Bronze Age: the zenith of the urban Canaanite era. Biblical Archaeologist 50:149-77.

Finkelstein I. 2013. Area M, Part III: another interpretation of the remains - the Nordburg and Chamber F. In: Finkelstein I, Ussishkin D, Cline EH, editors. Megiddo V: The 2004-2008 Seasons. Tel Aviv: Institute of Archaeology of Tel Aviv University. p 228-46.

Finkelstein I, Piasetzky E. 2007. Radiocarbon dating and Philistine chronology with an addendum on el-Ahwat. Egypt and the Levant XVII:73-82.

Finkelstein I, Piasetzky E. 2010a. Radiocarbon dating the Iron Age in the Levant: a Bayesian model for six ceramic phases and six transitions. Antiquity 84(324):374-85.

Finkelstein I, Piasetzky E. 2010b. The Iron I/IIA tran- 
sition in the Levant: a reply to Mazar and Bronk Ramsey and a new perspective. Radiocarbon 52(4):1667-80.

Finkelstein I, Piasetzky E. 2011. The Iron Age chronology debate: Is the gap narrowing? Near Eastern Archaeology 74(2):50-4.

Finkelstein I, Ussishkin D, Halpern B. 2006. Megiddo IV. The 1998-2002 Seasons. II. Tel Aviv: Institute of Archaeology of Tel Aviv University.

Franklin N. 2006. Area F (the 1998-2000 seasons). In: Finkelstein I, Ussishkin D, Halpern B, editors. Megiddo IV: The 1998-2002 Season. Tel Aviv: Institute of Archaeology of Tel Aviv University. p 54-65.

Franklin N. 2013. Area M, Part I: The excavation. In: Finkelstein I, Ussishkin D, Cline EH, editors. Megiddo V: The 2004-2008 Seasons. Tel Aviv: Institute of Archaeology of Tel Aviv University. p 178-214.

Gadot Y. 2009. Late Bronze and Iron Age pottery. In: Gadot Y, Yadin E, editors. Aphek-Antipatris II. The Remains of the Acropolis. The Moshe Kochavi and Pirhiya Beck Excavations. Tel Aviv: Institute of Archaeology of Tel Aviv University. p 182-341.

Gadot Y, Martin MAS, Blockman N, Arie E. 2006a. Area K: Levels K-5 and K-4, the 1998-2002 seasons. In: Finkelstein I, Ussishkin D, Halpern B, editors. Megiddo IV: The 1998-2002 Season. Tel Aviv: Institute of Archaeology of Tel Aviv University. p 87-103.

Gadot Y, Yasur-Landau A, Ilan D. 2006b. The Middle Bronze III and Late Bronze I pottery from Areas F and N. In: Finkelstein I, Ussishkin D, Halpern B, editors. Megiddo IV: The 1998-2002 Season. Tel Aviv: Institute of Archaeology of Tel Aviv University. p 171-90.

Gilboa A, Sharon I, Boaretto E. 2013. Radiocarbon dating of the Iron Age levels. In: Finkelstein I, Ussishkin D, Cline EH, editors. Megiddo V: The 2004 2008 Seasons. Tel Aviv: Institute of Archaeology of Tel Aviv University. p 1117-27.

Herzog Z, Singer-Avitz L. 2004. Redefining the centre: the emergence of state in Judah. Tel Aviv 31:209-44.

Herzog Z, Singer-Avitz L. 2006. Sub-dividing the Iron IIA in northern Israel: a suggested solution to the chronological debate. Tel Aviv 33:163-95.

Kempinski A. 1989. Megiddo. A City State and Royal Center in North Israel. Munich: Verlag C. H. Beck.

Kenyon K. 1960. Archaeology in the Holy Land. London: E. Benn.

Levy TE, Najjar M, Higham T. 2010. Ancient texts and archaeology revisited - radiocarbon and biblical dating in the southern Levant. Antiquity 84(325):834-47.

Martin MAS. 2009. Egyptian-type Eighteenth Dynasty pots at Megiddo. Egypt and the Levant XIX:211-8.

Martin MAS. 2011. Egyptian-Type Pottery in the Late Bronze Age Southern Levant. Vienna: Austrian Academy of Sciences Press

Martin MAS. 2013. The Late Bronze IIB pottery from Levels K-8 and K-7. In: Finkelstein I, Ussishkin D, Cline EH, editors. Megiddo V: The 2004-2008 Seasons. Tel Aviv: Institute of Archaeology of Tel Aviv
University. p 343-457.

Martin MAS, Blockman N, Bidmead J. 2013. Area K, Part I: Levels K-8 and K-7. In: Finkelstein I, Ussishkin D, Cline EH, editors. Megiddo V: The 2004 2008 Seasons. Tel Aviv: Institute of Archaeology of Tel Aviv University. p 153-64.

Mazar A. 1997. Archaeology of the Land of the Bible 10,000-586 BCE. New York: Doubleday.

Mazar A. 2007. Interpretation of the Radiocarbon dates from Area R. In: Mazar A, Mullins RA, editors. Excavations at Tel Beth-Shean 1989-1996, Volume II: The Middle and Late Bronze Age Strata in Area $R$. Jerusalem: Hebrew University of Jerusalem. p 71821.

Mazar A. 2009. Introduction and overview. In: Panitz-Cohen N, Mazar A, editors. Excavations at Tel Beth-Shean 1989-1996, Volume III: The 13th11 th century BCE strata in Areas $N$ and $S$. Jerusalem: Hebrew University of Jerusalem. p 1-32.

Mazar A. 2011. The Iron Age chronology debate: Is the gap narrowing? Another viewpoint. Near Eastern Archaeology 74(2):105-11.

Mazar A, Bronk Ramsey C. 2008. ${ }^{14} \mathrm{C}$ dates and the Iron Age chronology of Israel: a response. Radiocarbon 50(2):159-80

Mazar A, Bruins H, Panitz-Cohen N, van der Plicht H. 2005. Ladder of time at Tel Rehov: stratigraphy, archaeological context, pottery and radiocarbon dates. In: Levy TE, Higham T, editors. The Bible and Radiocarbon Dating: Archaeology, Text and Science. London: Equinox. p 193-255.

Mullins RA. 2007. The Late Bronze Age pottery. In: Mazar A, Mullins RA, editors. Excavations at Tel Beth-Shean 1989-1996, Volume II: The Middle and Late Bronze Age Strata in Area R. Jerusalem: Hebrew University of Jerusalem. p 390-547.

Panitz-Cohen N. 2006. The pottery of strata XII-V. In: Panitz-Cohen N, Mazar A, editors. Timnah (Tel Batash) III. The Finds from the Second Millennium $B C E$. Jerusalem: Hebrew University of Jerusalem. p 9-150.

Pechuro A. 2013. Area M, Part II: an architectural study of Chamber F. In: Finkelstein I, Ussishkin D, Cline EH, editors. Megiddo V: The 2004-2008 Seasons. Tel Aviv: Institute of Archaeology of Tel Aviv University. p 215-27.

Rebollo NR, Cohen-Ofri I, Popovitz-Biro R, Bar-Yosef O, Meignen L, Goldberg P, Weiner S, Boaretto E. 2008. Structural characterization of charcoal exposed to high and low $\mathrm{pH}$ : implications for ${ }^{14} \mathrm{C}$ sample preparation and charcoal preservation. $\mathrm{Ra}$ diocarbon 50(2):289-307.

Redford DB. 1979. A gate inscription from Karnak and Egyptian involvement in Western Asia during the early 18th Dynasty. Journal of the American Oriental Society 99(2):270-87.

Reimer PJ, Baillie MGL, Bard E, Bayliss A, Beck JW, Blackwell PG, Bronk Ramsey C, Buck CE, Burr GS, Edwards RL, Friedrich M, Grootes PM, Guilderson TP, Hajdas I, Heaton TJ, Hogg AG, Hughen 
KA, Kaiser KF, Kromer B, McCormac FG, Manning SW, Reimer RW, Richards DA, Southon JR, Talamo S, Turney CSM, van der Plicht J, Weyhenmeyer CE. 2009. IntCa109 and Marine09 radiocarbon age calibration curves, $0-50,000$ years cal BP. Radiocarbon 51(4):1111-50.

Seger JD. 1975. The MB II fortifications at Shechem and Gezer: a Hyksos retrospective. Eretz-Israel 12:34-45.

Sharon I. 2001. 'Transition dating' - a heuristic mathematical approach to the collation of radiocarbon dates from stratified sequences. Radiocarbon 43(2A):345-54.

Sharon I, Gilboa A, Jull AJT, Boaretto E. 2007. Report on the first stage of the Iron Age dating project in Israel: supporting a Low Chronology. Radiocarbon 49(1):1-46.

Stockhammer P. 2011. An Aegean glance at Megiddo. In: Gauss W, Lindblom M, Smith RAK, Wright JC, editors. Our Cups are Full: Pottery and Society in the Aegean Bronze Age. Papers Presented to Jeremy B. Rutter on the Occasion of his 65th Birthday. Oxford: Archaeopress. p 282-96.
Stuiver M, Polach HA. 1977. Discussion: reporting of ${ }^{14} \mathrm{C}$ data. Radiocarbon 19(3):355-63.

Toffolo MB, Maeir AM, Chadwick JR, Boaretto E. 2012. Characterization of contexts for radiocarbon dating: results from the early Iron Age at Tell es-Safi/Gath, Israel. Radiocarbon 54(3-4):371-90.

van der Plicht H, Bruins HJ, Nijboer AJ. 2009. The Iron Age around the Mediterranean: a High Chronology perspective from the Groningen radiocarbon database. Radiocarbon 51(1):213-42.

Weinstein J. 1981. The Egyptian Empire in Palestine: a reassessment. Bulletin of the American Schools of Oriental Research 241:1-28.

Yizhaq M, Mintz G, Cohen I, Khalaily H, Weiner S, Boaretto E. 2005. Quality controlled radiocarbon dating of bones and charcoal from the early Pre-Pottery Neolithic B (PPNB) of Motza (Israel). Radiocarbon 47(2): 193-206.

Zimhoni O. 2004. The pottery of Levels III and II. In: Ussishkin D, editor. The Renewed Archaeological Excavations at Lachish (1973-1994). Tel Aviv: Institute of Archaeology of Tel Aviv University. p 1789-899. 